\title{
Biallelic modification of IL2RG leads to severe combined immunodeficiency in pigs
}

\author{
Jung-Taek Kang ${ }^{1}$, Bumrae Cho', Junghyun Ryu ${ }^{3}$, Caitlin Ray ${ }^{3}$, Eun-Jin Lee', Yun-Jin Yun', SunMi Ahn', JinSeok Lee',
} Dal-Young Ji ${ }^{1}$, Nathaniel Jue ${ }^{4}$, Sherrie Clark-Deener ${ }^{4}$, Kiho Lee ${ }^{3^{*}}$ and Kwang-Wook Park ${ }^{1,2^{*}}$

\begin{abstract}
s
Background: Pigs with SCID can be a useful model in regenerative medicine, xenotransplantation, and cancer cell transplantation studies. Utilizing genome editing technologies such as CRISPR/Cas9 system allows us to generate genetically engineered pigs at a higher efficiency. In this study, we report generation and phenotypic characterization of IL2RG knockout female pigs produced through combination of CRISPR/Cas9 system and SCNT. As expected, pigs lacking IL2RG presented SCID phenotype.

Methods: First, specific CRISPR/Cas9 systems targeting IL2RG were introduced into developing pig embryos then the embryos were transferred into surrogates. A total of six fetuses were obtained from the embryo transfer and fetal fibroblast cell lines were established. Then IL2RG knockout female cells carrying biallelic genetic modification were used as donor cells for SCNT, followed by embryo transfer.
\end{abstract}

Results: Three live cloned female piglets carrying biallelic mutations in IL2RG were produced. All cloned piglets completely lacked thymus and they had a significantly reduced level of mature T, B and NK cells in their blood and spleen.

Conclusions: Here, we generated IL2RG knockout female pigs showing phenotypic characterization of SCID. This IL2RG knockout female pigs will be a promising model for biomedical and translational research.

Keywords: IL2RG, Severe Combined Immunodeficiency (SCID), CRISPR/Cas9, Somatic cell nuclear transfer (SCNT), Knockout pigs

\section{Background}

The IL2RG gene, located on the $\mathrm{X}$ chromosome, encodes the common gamma chain protein [35], which is a subunit of various interleukin receptors that are involved in immune system. The receptor is a key part of major lymphocytes, therefore, supports the growth and maturation of several subtypes of lymphocytes: $\mathrm{T}$ cells, B cells, and natural killer (NK) cells. These lymphocytes are an essential component of the adaptive and innate immune system. Deletion or mutation in the IL2RG gene would lead to the loss of functional immune system. Specifically, IL2RG mutation results in X-linked severe combined immunodeficiency (XSCID), characterized by profound defects in cellular and humoral immunity in humans $[2,17,24]$. Transgenic mice lacking functional $I L 2 R G$

\footnotetext{
* Correspondence: kiholee@exchange.vt.edu; parkmgen@hanmail.net ${ }^{3}$ Department of Animal and Poultry Sciences, Virginia Tech, Blacksburg, VA, USA

${ }^{1}$ MGENPLUS Biotechnology Research Institute, Seoul 08511, South Korea Full list of author information is available at the end of the article
}

exhibits SCID phenotypes due to limited number of mature $\mathrm{B}$ and $\mathrm{T}$ cells and the loss of NK cells [3]. These mice have been a useful resource for immunological, inflammation, oncology, and stem cell transplantation studies [9, 32, 36]. However, rodent models do not always recapitulate the genetic and physiological states of humans. In fact, there are significant differences in immune system between mice and humans [22]. For example, expression and ligand specificity of Toll-like receptors, which can activate innate immune are different between human and mouse [43]. Likewise, post-inflammatory genomic responses in mouse models poorly mimic human [31]. In addition, because of their size and shorter lifespan compared to humans, mouse models are not ideal to carry out surgical and clinical procedures or employ long-term tracking and evaluation of tissue or cell transplantation. Therefore, immunological assessments and procedures developed using SCID mice as a 
model may not translate directly into the same outcomes in humans.

Pigs are considered to be a leading large animal model in biomedical research because they share similar anatomy and physiology with humans [26]. Various pig models have been generated to study human diseases such as cystic fibrosis [28], diabetes mellitus [27], Alzheimer's disease [13], and retinitis pigmentosa [29]. SCID pigs, in particular, can be a useful model in regenerative medicine, xenotransplantation, and cancer cell transplantation researches because of similarities in immune system between pigs and humans. Disruption of IL2RG in male pigs resulted in immunodeficiency presented in X-linked SCID patients [34]; these pigs lacked $\mathrm{T}$ and NK cells [34, 38]. Disruption of other key genes related to immune response also resulted in the production of SCID pigs lacking $\mathrm{T}$ and $\mathrm{B}$ cells $[8,14]$.

Conventionally significant effort is required to generate these SCID pigs due to technical limitations. However, recent advancement in genome editing technologies such as CRISPR/Cas9 system allows us to generate genetically engineered pigs at a higher efficiency and in a short period of time, less than six months $[14,16]$. The CRISPR/Cas9 system, originated from a natural microbial immune system [1], consists of a RNA-guided Cas9 endonuclease, a single guide RNA (sgRNA), and the trans-activating CRISPR RNA (tracrRNA) which have been engineered for genome editing in eukaryotic cells [4]. This CRISPR/Cas9 system has emerged as an efficient and powerful tool for gene editing $[11,39]$, and been successfully applied in many mammals, including mice, rats, pigs, and monkeys [6, 18, 19, 23, 37].

Here, we applied CRISPR/Cas9 technology to target $I L 2 R G$ during porcine embryogenesis, and generated IL2RG knockout fibroblast cells from fetuses derived from the embryos. Then the IL2RG knockout cells were used as nuclear donors to produce IL2RG knockout female pigs by somatic cell nuclear transfer (SCNT). As a result, SCID pig models lacking mature lymphocytes were generated, which could be a valuable large animal model for human disease research or biomedical study.

\section{Methods}

\section{Reagents}

All chemicals in the study were purchased from SigmaAldrich Chemical Company (St. Louis, MO, USA) unless indicated otherwise.

\section{Animals}

All experiments involving animals were approved by the Institutional Animal Care and Use Committee of the institute of MGENPLUS co., Korea, and Virginia Tech (\#14-019). All the procedures were conducted under the guidelines of the Committee. All surgical procedures were performed under general anesthesia, and all necessary efforts were made to minimize any potential suffering of animals. Pigs were maintained under conventional housing conditions.

\section{Design and construction of IL2RG targeting CRISPR/Cas9 system}

The sgRNA that could recognize porcine IL2RG gene were designed using an online CRISPR design tool (http:// zifit.partners.org/ZiFiT/Disclaimer.aspx). Sequence information of the designed sgRNAs is 5'-CGAAGGTCCTCA CGCACAGTGGG-3' (gRNA \#1) and 5'-CCGAAGGT CCTCACGCACAGTGG-3' (gRNA \#2), respectively. The PAM can be identified by the bold font in each sgRNA. Specificity of the designed sgRNAs was confirmed by searching for similar porcine sequences in GenBank. Both sgRNAs are designed to create DSB in exon 1 of IL2RG. The sgRNA sequences were introduced into the px330 vector (Addgene) as described previously (Additional file 1: Table S1) [40]. Then the targeting vectors were used as a template to generate sgRNA and Cas9 mRNA through in vitro transcription (Additional file 1: Table S2).

\section{Generation of IL2RG knockout fetuses by direct injection of CRISPR/Cas9 system into early embryos}

For in vitro maturation, cumulus oocyte complex (COC) were maturated in vitro in a TCM-199 based maturation media containing $0.5 \mathrm{IU} / \mathrm{ml} \mathrm{FSH}, 0.5 \mathrm{IU} / \mathrm{ml} \mathrm{LH}$, $0.82 \mathrm{mM}$ cysteine, $3.02 \mathrm{mM}$ glucose, $0.91 \mathrm{mM}$ sodium pyruvate, and $10 \mathrm{ng} / \mathrm{ml}$ EGF. After $42-44 \mathrm{~h}$ of maturation, cumulus cells were removed by incubating the oocytes into a media containing $0.1 \%$ hyaluronidase. Oocytes that extruded the first polar body were used for in vitro fertilization (IVF). Then mature oocytes, groups of 25-30 oocytes, were placed in $50 \mu 1$ droplets of IVF medium (modified Tris-buffered medium with $113.1 \mathrm{mM}$ $\mathrm{NaCl}, 3 \mathrm{mM} \mathrm{KCl}$, $7.5 \mathrm{mM} \mathrm{CaCl}_{2}, 11 \mathrm{mM}$ glucose, $20 \mathrm{mM}$ Tris, $2 \mathrm{mM}$ caffeine, $5 \mathrm{mM}$ sodium pyruvate, and $2 \mathrm{mg} / \mathrm{ml}$ BSA). Extended semen was washed with PBS three times then the sperm pellet was resuspended with $\mathrm{mTBM}$ media. Then, $50 \mu \mathrm{l}$ sperm $\left(2.5 \times 10^{5} \mathrm{sperm} / \mathrm{ml}\right)$ was introduced into mTBM drops that contained oocytes. The gametes were co-incubated for $5 \mathrm{~h}$. Presumptive fertilized embryos were then placed in Porcine Zygote Media 3 (PZM-3) [41] at $38.5{ }^{\circ} \mathrm{C}, 5 \% \mathrm{CO}_{2}$, and $5 \% \mathrm{O}_{2}$ incubator until microinjection of CRISPR/Cas9 system. After 2-4 h post-IVF, presumable zygotes were injected with RNA form of CRISPR/Cas9 system to target IL2RG. Concentrations of $10 \mathrm{ng} / \mu \mathrm{l}$ sgRNA and $20 \mathrm{ng} / \mu \mathrm{l}$ Cas 9 mRNA was injected into the cytoplasm of fertilized oocytes using a FemtoJet microinjector (Eppendorf, Hamburg, Germany). Microinjection was conducted in manipulation medium (TCM199 with $0.6 \mathrm{mM} \mathrm{NaHCO}, 2.9 \mathrm{mM}$ HEPES, $30 \mathrm{mM} \mathrm{NaCl}, 10 \mathrm{ng} / \mathrm{ml}$ gentamicin, and $3 \mathrm{mg} / \mathrm{ml} \mathrm{BSA}$ ) on 
the heated stage of a Nikon inverted microscope (Nikon Corporation, Tokyo, Japan). Injected zygotes were washed then transferred and cultured into PZM-3. Embryos used for embryo transfer were cultured in PZM-3 in the presence of $10 \mathrm{ng} / \mathrm{ml}$ GM-CSF [15] until embryo transfer. A total of 245 microinjected embryos were transferred into two surrogate sows at day 5 or 6 post-IVF. The embryos were surgically transferred into the oviduct of the sows.

\section{Establishing fibroblast cells from IL2RG knockout fetuses}

For the collection of fetal fibroblast cells, porcine fetuses were obtained on day 40 of gestation. Genomic DNAs were isolated from each fetus using PureLink Genomic DNA kit (Thermo Fisher Scientific, Waltham, MA, USA) following the manufacturer's instructions. PCR to genotype modifications on IL2RG was conducted using Platinum Taq DNA Polymerase (Thermo Fisher Scientific). PCR conditions were as follows, initial denature at $95{ }^{\circ} \mathrm{C}$ for $2 \mathrm{~min}$, denature at $95^{\circ} \mathrm{C}$ for $30 \mathrm{~s}$, annealing at $55{ }^{\circ} \mathrm{C}$ for $30 \mathrm{~s}$ and extension at $72{ }^{\circ} \mathrm{C}$ for $30 \mathrm{~s}$ for $34 \mathrm{cy}$ cles. The amplicons were sent to VBI (Biocomplexity institute of Virginia) for sequencing (primer information is in Additional file 1: Table S3). Using extended primers, fetus \#3 and \#6 were conducted PCR again. PCR conditions were as follows, initial denature at $95^{\circ} \mathrm{C}$ for $2 \mathrm{~min}$, denature at $95{ }^{\circ} \mathrm{C}$ for $30 \mathrm{~s}$, annealing at $55^{\circ} \mathrm{C}$ for $30 \mathrm{~s}$ and extension at $72{ }^{\circ} \mathrm{C}$ for 2 min for 34 cycles. The fetuses were cut into small pieces and digested with $0.25 \%$ trypsin-0.02\% EDTA for $30 \mathrm{~min}$ at $37{ }^{\circ} \mathrm{C}$. Following trypsinization, the cells were washed by centrifugation and subsequently seeded on to culture dishes and cultured in DMEM (Gibco BRL, Grand Island, NY, USA) supplemented with $15 \%$ fetal bovine serum (HyClone \#AVM90621, USA) and $1 \%$ penicillin/streptomycin under $5 \% \mathrm{CO}_{2}$ at $37.5{ }^{\circ} \mathrm{C}$. After 3 days of culture the tissue explants were removed by rinsing the flask with Dulbecco's phosphate buffered saline (DPBS; Gibco $\mathrm{BRL}$ ) and the remaining attached fibroblast cells were cultured until confluence.

\section{Detection of mutations on IL2RG generated by the CRISPR/Cas9 system}

Genomic DNA from each cell colony was extracted using a DNA extraction kit (iNtRon Biotechnology, Seongnam-si, Korea), following the manufacturer's instructions. To confirm genetic modifications on IL2RG from the cell colonies, PCR was conducted using $2 \times$ Taq. Premix (PCR Biosystems, London, UK). PCR was performed at 40 cycles with porcine IL2RG specific primers using the following conditions; one cycle of initial-denaturation at $95{ }^{\circ} \mathrm{C}$ for 5 min followed by 40 cycles of denaturation at $95{ }^{\circ} \mathrm{C}$ for $60 \mathrm{~s}$, annealing at $52{ }^{\circ} \mathrm{C}$ for $30 \mathrm{~s}$, and elongation at $72{ }^{\circ} \mathrm{C}$ for $30 \mathrm{~s}$, and a cycle of postelongation at $72{ }^{\circ} \mathrm{C}$ for $10 \mathrm{~min}$. Additional file 1: Table S3 shows sequences of primers used for genotyping. Mutations on IL2RG gene were assessed by digesting PCR amplicons with the T7 endonuclease I (T7E1) enzyme as previously described [12]. The PCR products from the DNA isolated from colonies were denatured at $95^{\circ} \mathrm{C}$ for $5 \mathrm{~min}$ and re-annealed at room temperature for $10 \mathrm{~min}$, then digested by T7E1 (ToolGen labs, Seoul, Korea) at $37{ }^{\circ} \mathrm{C}$ for $0.5 \mathrm{~h}$. Digestion of the PCR products was expected if the colony contained mutated IL2RG. PCR products with potential modification of IL2RG were confirmed by sequencing.

\section{Somatic cell nuclear transfer and embryo transfer}

SCNT was performed as described in previous studies $[12,42]$. Pig ovaries were collected from a local abattoir and transported to the laboratory in $0.9 \%(\mathrm{w} / \mathrm{v}) \mathrm{NaCl}$ solution at $25-30{ }^{\circ} \mathrm{C}$. Oocytes were aspirated from antral follicles (3-6 $\mathrm{mm}$ in diameter) and cultured in maturation medium at $39{ }^{\circ} \mathrm{C}$ with $5 \% \mathrm{CO}_{2}$ at $100 \%$ humidity. After $44 \mathrm{~h}$ of maturation, denuded oocytes which extruded the first polar body were used for SCNT. Mature MII oocytes were enucleated by aspirating the first polar body and adjacent cytoplasm with a thin glass pipette (20 um in diameter) in manipulation medium supplemented with cytochalasin B (5 mg/ml stock, $1.5 \mathrm{ul}$ per $10 \mathrm{ml}$ manipulation medium). Then a single donor cell was injected into the perivitelline space of enucleated oocytes. Oocyte cytoplasm-cell complexes were then fused and activated by electric pulse (ECM 2001; BTX Inc., San Diego, CA, USA, two DC pulses of $1.1 \mathrm{kV} / \mathrm{cm}$ for $60 \mu \mathrm{sec})$. Reconstructed embryos were cultured in PZM3 in $5 \% \mathrm{CO}_{2}$ at $39{ }^{\circ} \mathrm{C}$ with $0.5 \mathrm{uM}$ Scriptaid, a histone deacetylase inhibitor, for 14-16 h. Embryos with an intact plasma membrane were surgically transferred into the oviduct of a surrogate (average 230 embryos) at the two day after observed estrus. Successful pregnancy was assessed by an ultrasound at day 28 days post embryo transfer. The gestation was monitored every 2 weeks. After approximately 114 days, cloned piglets were delivered by c-section from recipients. On the day of birth, a tale biopsy was performed on each piglet for genomic DNA extraction and genotyping.

\section{Flow Cytometric Analysis (FACS)}

Peripheral blood mononuclear cells (PBMCs) and splenocytes were isolated from whole blood and spleen from IL2RG knockout pigs and age-matched control pigs. To identify $\mathrm{CD}^{+}, \mathrm{CD}^{+}$, and $\mathrm{CD}^{+} \mathrm{T}$ cells and $\mathrm{CD} 21^{+} \mathrm{B}$ cells, mouse anti-pig CD3e (Southern Biotech, AL, USA), CD4a, CD8a, and mouse anti-human CD21 (BD Pharmingen, CA, USA) were used in this study. Mouse anti-pig CD16 (AbD Serotec, NC, USA) and mouse anti-pig monocyte and granulocyte (M/G, BD Pharmingen, CA, USA) were also used in this study for detection of NK cell population. A total of $5 \times 10^{5}$ 
PBMCs or splenocytes were incubated with the indicated Abs for 40 min at $4{ }^{\circ} \mathrm{C}$ and washed twice with PBE. At least 10,000 cells were analyzed per run. Samples were analyzed using a FACS Calibur system with CELLQUEST software (BD Bioseciences, CA, USA). Each experiment was repeated at least three times.

\section{Histological analysis}

Spleens from IL2RG knockout and age-matched wildtype pigs were first fixed in $10 \%$ neutral buffered formalin. The fixed tissues were embedded in paraffin and sectioned for $H \& E$ staining and immunohistochemistry (IHC). In IHC, rabbit anti-pig CD3 antibody (abcam, MA, USA) as T lymphocytes marker and mouse anti-pig CD79a antibody (abcam, MA, USA) as B lymphocytes marker were used for analysis of distribution of $\mathrm{T}$ and $\mathrm{B}$ lymphocytes.

\section{Results}

\section{Design of CRISPR/Cas9 vector and isolation of IL2RG} knockout cells

Porcine IL2RG is located on the $\mathrm{X}$ chromosome and consists of 8 exons [7]. In this study, we constructed CRISPR/Cas9 systems that can target exon 1 of porcine IL2RG, which contains the first translation initiation site (Fig. 1a). Schematic construction of the CRISPR/Cas9 system used in this study is shown in Fig. 1b. When $10 \mathrm{ng} / \mu \mathrm{l}$ sgRNA and $20 \mathrm{ng} / \mu \mathrm{l}$ Cas 9 mRNA were introduced into developing embryos and subsequent embryos were genotyped, all embryos carried mutations in IL2RG; no wild-type sequence was found from the in vitro analysis (Table 1). Transferring IVF embryos injected with the RNA form of CRISPR/Cas9 system resulted in one pregnancy (Table 2) and six fetuses were collected from the surrogate to establish IL2RG knockout cell lines. The fetuses and cell lines were screened by the T7E1 assay and PCR DNA sequencing to detect potential mutation generated by the CRISPR/Cas9 system. Mutations in the IL2RG were found in fetus \#1, \#2, \#4, and \#5. No PCR amplicon was acquired from fetuses \#3 and \#6 even by using extended primers, suggesting that two fetus carried large deletions ( $>2 \mathrm{~kb}$ ) by CRISPR/Cas 9 system (Fig. 1c). The efficacy of introducing mutations in the IL2RG was $100 \%$ (Additional file 1: Table S4). Genotyping fetus \#4 indicated that the cells carried biallelic mutation ( 2 bp or 93 bp deletion) in IL2RG. The cells were used to generate IL2RG knockout female pigs (Fig. 1d). The results demonstrate that the CRISPR/Cas9-mediated targeting is effective in generating mutations in the genome of porcine developing embryos.

\section{Production of IL2RG knockout pigs}

IL2RG knockout pigs were produced by SCNT from the targeted fibroblast cells. Reconstructed embryos were transferred to three surrogates, and one of the surrogates had a full-term pregnancy (Table 2). Three female cloned pigs were obtained from the recipient via cesarean section (Fig. 2a). PCR genotyping, T7E1 assay and DNA sequence analyses of the 3 cloned pigs showed that all 3 pigs had the same mutation as the nuclear donor cells ( 2 bp and 93 bp deletion, Fig. 2b). Three survivors died from pneumonia and severe arthritis or (a)

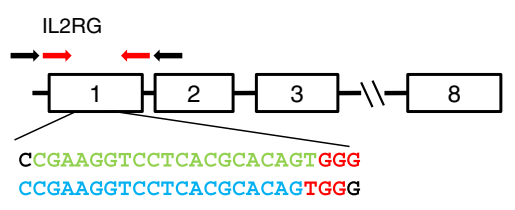

(c)

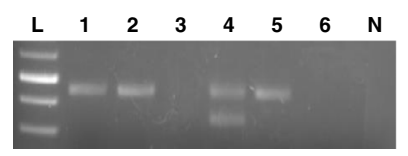

(b)

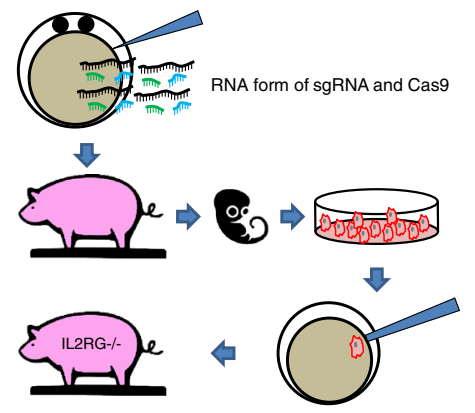

(d)

\begin{tabular}{|c|l|c|}
\hline Fetus Number & \multicolumn{1}{|c|}{ Sequence } & Mutation \\
\hline Wild type & TCACGCACAGTGGG & \\
\hline$\# 4$ & $\begin{array}{l}\text { TCACG--CAGTGG ( } 2 \text { bp }) \\
\text { ATGAATGAAG- }-(-93 \mathrm{bp})-\text {-ACATCACAGCTG }\end{array}$ & Biallelic mutation \\
\hline
\end{tabular}

Fig. 1 Use of CRISPR/Cas9 system to disrupt IL2RG in pigs. a Design of CRISPRs to target IL2RG. Sequences in green and blue indicate target sequences and letters in red reflect PAM (NGG) sequences. Red arrows indicate the location of primers used to genotype embryos and piglets. Black arrows indicate the location of extended primers. $\mathbf{b}$ Schematic strategy used to produce IL2RG deficient pigs. IL2RG knockout cells lines were established from fetuses derived from CRISPR/Cas9 injected embryos. SCNT was performed to generate IL2RG knockout female pigs. c PCR amplification to genotype IL2RG knockout fetuses. Various mutations were detected from fetus 1, 2, 4, and 5. d Genotype of IL2RG knockout cell line used for SCNT 4. Bold letters indicate insertion or change in nucleotides, and '-' indicates deletion of nucleotide 
Table 1 Efficacy of CRISPR/Cas9 system to induce targeted disruption of IL2RG during embryogenesis in vitro. CRISPR/Cas9 system at the concentration of $10 \mathrm{ng} / \mathrm{ul}$ each sgRNAs and $20 \mathrm{ng} / \mathrm{ul}$ Cas9 mRNA was introduced into pig zygotes. Genotyping of subsequent embryos on day 7 demonstrated that all embryos carried mutation on IL2RG; no wild type sequence was found from genotyping

\begin{tabular}{|c|c|c|c|c|c|c|c|c|}
\hline \multirow{2}{*}{$\begin{array}{l}\text { Concentration } \\
\text { of CRISPR/Cas9 } \\
\text { (ng/uL) }\end{array}$} & \multirow{2}{*}{$\begin{array}{l}\text { \# of embryos } \\
\text { injected }\end{array}$} & \multirow{2}{*}{$\begin{array}{l}\% \text { of blastocyst on } \\
\text { day } 7 \text { (number } \\
\text { of blastocysts/ } \\
\text { cleaved) }\end{array}$} & \multirow{2}{*}{$\begin{array}{l}\text { \# of blastocyst } \\
\text { genotyped }\end{array}$} & \multicolumn{5}{|l|}{ Genotypes } \\
\hline & & & & $\begin{array}{l}\text { Homozygous } \\
\text { Mutation }\end{array}$ & $\begin{array}{l}\text { Biallelic } \\
\text { Mutation }\end{array}$ & $\begin{array}{l}\text { Mosaic } \\
\text { Mutation }\end{array}$ & $\begin{array}{l}\text { Heterozygous } \\
\text { Mutation }\end{array}$ & Wild-type \\
\hline $10 / 20$ & 70 & $\begin{array}{l}25.71 \% \\
(18 / 70)\end{array}$ & 4 & 0 & 2 & 2 & 0 & 0 \\
\hline
\end{tabular}

unknown cause(s) (all were euthanized) between postnatal day 1 (P1) and P12.

\section{Phenotypic characterization of IL2RG knockout pigs}

All piglets were raised under standard housing conditions and all the IL2RG knockout piglets presented health issues. Necropsy results from the knockout pigs and age-matched wild-type demonstrated that the IL2RG piglets were immunodeficient. The biallelic IL2RG knockout piglets lacked thymus compared with agematched wild-type pigs (Fig. 2c). Although there was no obvious difference in size, the spleens of biallelic IL2RG knockout pigs were much thinner and more loosely packed than those of age-matched wild-type pigs. The spleens were fixed and embedded for H\&E staining to further analyze its inner structure and cell composition. The spleens of biallelic IL2RG knockout pigs were hypoplastic in the central artery of periarterial lymphatic sheath, and lacked white pulp (Fig. 2c). In IHC, CD3 positive $\mathrm{T}$ lymphocytes and CD79 $\alpha$ positive B lymphocytes were absent or less existed in collected spleen samples of all piglets, showing that the number of lymphocytes was remarkably reduced in the biallelic IL2RG knockout pigs compared with the wild-type controls (Fig. 2c). However, one littermate having longest survival period (d12) have some $\mathrm{CD} 79 \alpha$ positive $\mathrm{B}$ lymphocytes alike other littermate.

To detect the status of B, T lymphocytes and NK cells in the biallelic knockout pigs, cells were collected from

Table 2 Embryo transfer results. A total of five embryo transfers were performed in this study. Transferring CRISPR/Cas9 injected IVF embryos was to generate IL2RG knockout fetuses. IL2RG knockout piglets were produced by transferring SCNT embryos

\begin{tabular}{llllll}
\hline $\begin{array}{l}\text { Surrogate } \\
\text { ID }\end{array}$ & $\begin{array}{l}\text { Number of } \\
\text { embryos } \\
\text { generated }\end{array}$ & $\begin{array}{l}\text { Number of } \\
\text { embryos } \\
\text { transferred } \\
\text { into a } \\
\text { recipient }\end{array}$ & $\begin{array}{l}\text { Source of } \\
\text { embryos }\end{array}$ & pregnancy & $\begin{array}{l}\text { Number of } \\
\text { Fetus/piglets }\end{array}$ \\
\hline $73-10$ & 128 & 124 & IVF & No & - \\
Y463 & 117 & 93 & IVF & Yes & 6 \\
$104-154$ & 262 & 262 & SCNT & Yes & 3 \\
$28-35$ & 283 & 283 & SCNT & No & - \\
$27-78$ & 352 & 352 & SCNT & No & - \\
\hline
\end{tabular}

spleen and whole blood. Then the cells were used to perform FACS assay. Staining the splenocytes and PBMC with CD3, CD4 and CD8 Abs demonstrated that the biallelic knockout pigs had almost no CD4/CD8 single- and double-positive $(+)$ cells compared with the wild-type controls. The ratio of $\mathrm{CD}^{+} \mathrm{CD}^{+}$and $\mathrm{CD} 3$ ${ }^{+} \mathrm{CD}^{+}$cells also decreased drastically in the knockout pigs, whereas ratios of about $20 \%$ (respectively) were observed in the wild-type counterparts, indicating the lack of $\mathrm{T}$ lymphocytes in $\mathrm{PB}$ and spleen. The average number of $\mathrm{B}$ cell $\left(\mathrm{CD} 21^{+}\right)$was significantly lower in the knockout piglets compared with the wild-type. However, $B$ cells were detected from a cloned piglet with the longest survival period (P12); the level was $36.7 \%$, similar to $36.5 \%$ in spleen of wildtype, compared with other littermate lacking B cells (4.86 \%). This result is consistent with $\mathrm{IHC}$ result. The number of NK cells $\left(\mathrm{M} / \mathrm{G}^{-}, \mathrm{CD} 16^{+}\right)$ was notably lower in IL2RG knockout pigs than wild-type pigs (Fig. 3).

\section{Discussion}

IL2RG is responsible for growth and maturation of immune cells such as T cells and NK cells because it is a common component of many interleukin receptors. In this study, we generated IL2RG knockout pigs by using CRISPR/Cas9 system-mediated gene targeting strategy. These knockout pigs presented SCID phenotype as expected. Because of the SCID phenotype, the IL2RG knockout pigs can be used as research model for in vivo stem cell repopulation. IL2RG homozygous knockout mouse model has been an excellent recipient model for engraftment of human cells [10]. For instance, IL2RG null mice have significantly improved engraftment results compared with other immunocompromised SCID model when human cord blood engraftment was attempted [21]. The IL2RG knockout pig model can be a more useful animal model considering the discrepancy between immune cell function and the immune system of humans and rodents.

In this study, we injected CRISPR/Cas9 systems directly into developing embryos to target IL2RG. The efficacy of this approach was effective as all resulting embryos and fetuses carried mutation in IL2RG. Because the approach may lead to animals with different 
(a)

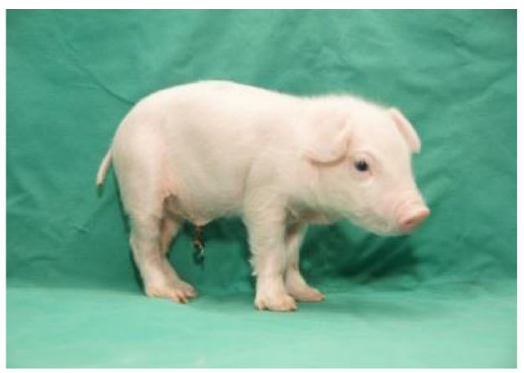

(b)

\begin{tabular}{|c|c|c|c|}
\hline WT & $\begin{array}{l}\text { GGGACTGAACCCGAAGGTCCTCACGCACAGTGGGAATGAAGACATC } \\
\text { GGGACTGAACCCGAAGTTCTCACGCACAGTGGGAATGAAGACATC }\end{array}$ & $\begin{array}{l}\text { WT } \\
\text { WT }\end{array}$ & Target $^{-1-}$ \\
\hline $\begin{array}{c}\text { piglet } \\
\# 1\end{array}$ & $\begin{array}{l}-1-1 \\
\text { GGGACTGAACCCGAAGGTCCTCACGCA--GTGGGAATGAAGACATC }\end{array}$ & $\begin{array}{l}\triangle 93 \\
\triangle 2\end{array}$ & Target $^{-{ }^{-}}$ \\
\hline
\end{tabular}

(c)

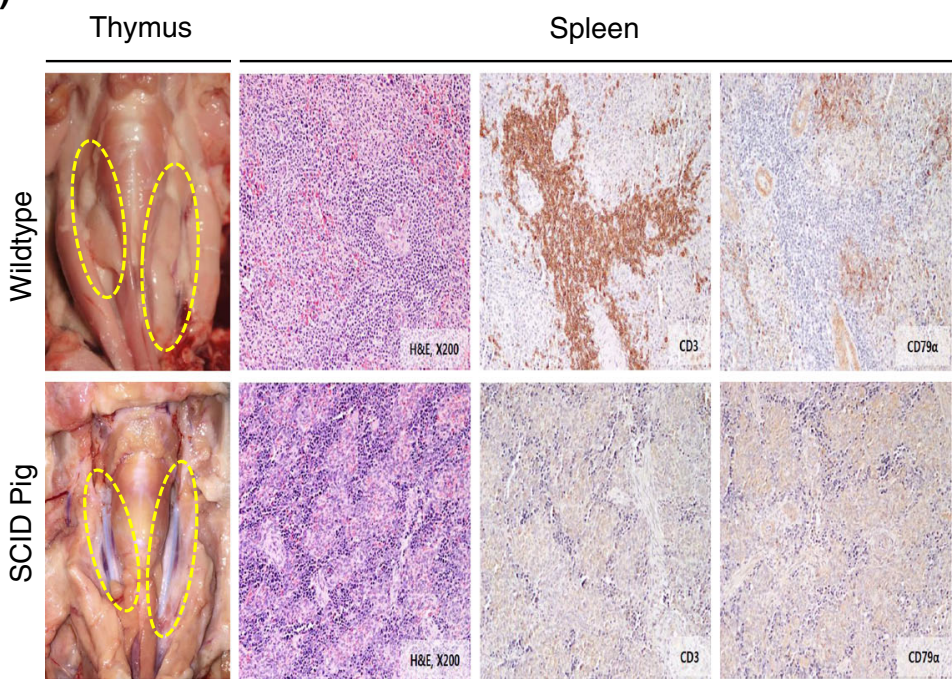

Fig. 2 Generation of IL2RG knockout pigs. a An image of IL2RG knockout pigs produced in this study (b) Genotypes of IL2RG knockout female piglets. The dots indicate the deletion mutation in the sequence of IL2RG knockout pigs. c Immunodeficiency presented in IL2RG knockout pigs. The thymic phenotype in IL2RG knockout pigs shows absence of thymus compared to normal thymuses in wild-type pigs. Dotted yellow circle indicates the location of thymus. The histological analysis of the spleens of wild-type and IL2RG knockout pigs indicate that IL2RG knockout pigs lack T and B cells (Original magnification 200x)

genotypes and mosaicism [20], fetal fibroblast cells from each fetus were genotyped and used for SCNT to generate IL2RG knockout pigs. With this approach, exact genotype of nuclear donor cells can be identified prior to the production of cloned animals; this can assure the production of animals only carrying desired modification. Using this approach, IL2RG knockout pigs were produced at a higher rate compared to traditional gene targeting approach which utilizes endogenous homologous recombination mechanism in somatic cells. Because IL2RG is located on the $\mathrm{X}$ chromosome and generating animals carrying multi-allelic modifications is challenging, previous reports of IL2RG knockout pigs were all in male [38]. However, using the CRISPR/Cas9 system, we could generate female IL2RG deficient pigs.
A recent study demonstrates generation of RAG2/IL2RG knockout females [16], however, to our best knowledge, this is the first report of female IL2RG deficient pigs.

Opportunistic infections in SCID animals after birth are unavoidable under conventional housing conditions. We therefore recovered full-term IL2RG knockout piglets recovered via cesarean section (114 d of gestation) to avoid any risk of infection during parturition. However, the IL2RG knockout pigs could not thrive and only lasted a short period ( $<12$ days) because of unavoidable opportunistic infection due to their SCID condition under conventional housing conditions, not pathogenfree facilities..At postmortem examination, these animals have showed a pleural fluid inside the thoracic cavity, supporting evidence of infection (data not shown). The 


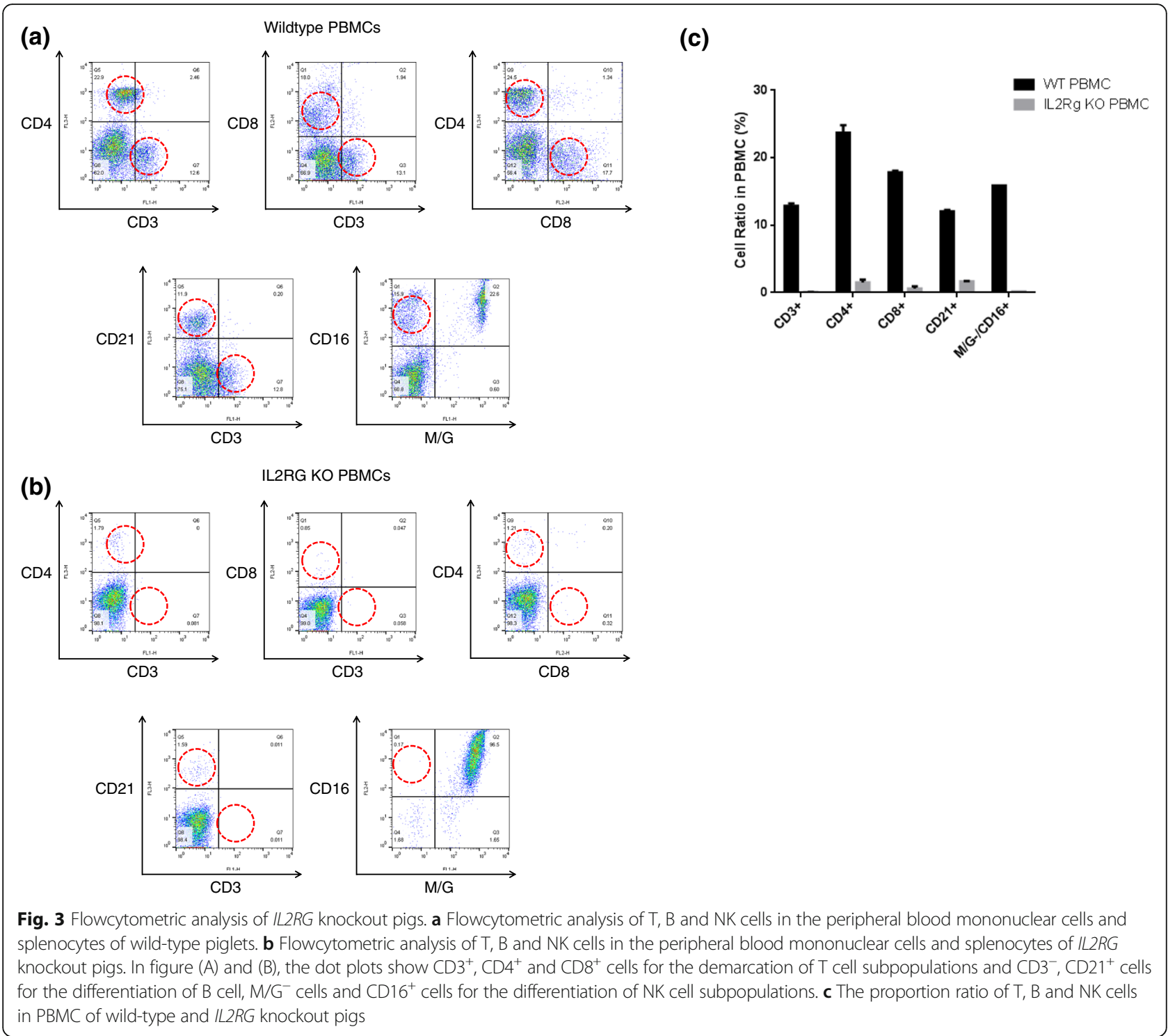

early death of the IL2RG knockout pigs is probably because of deficient in functional immune system. Generally, long-term maintenance of severely immunodeficient animals would require housing under pathogen-free conditions. Therefore, management of additional IL2RG animals should be conducted at facilities severely controlled against exogenous pathogens.

A marked decrease in the number of $\mathrm{T}$ and $\mathrm{B}$ cells has been reported in XSCID mice $[3,5]$ and rat [20]. In human XSCID patients, although the number of $\mathrm{T}$ and NK cells is significantly decreased, the number of B cells remains normal or is occasionally increased [2, 33]. Similarly, IL2RG knockout pigs produced in previous studies lacked $\mathrm{T}$ and NK cells but showed normal B cell populations, and identical phenotypic characteristics were shown identically in human XSCID [34, 38]. However, some IL2RG knockout pigs obtained in this study showed an absent or lower B cell population; the level of $\mathrm{T}$ and NK cells was lower as expected, although one littermate have similar B cell population with control. This discrepancy could come from gender biased effect. As mentioned above, all the previous reports of IL2RG modifications in pigs were in males. And most of human XSCID cases are also in male. Interestingly, some reports in mice indicate that there is difference in immune responses of SCID mice based on the gender. Female SCID mice were more effective in supporting engraftment of foreign cells compared to their male counterpart [21, 25]. Specifically, repopulation experiment of human hematopoietic stem cells using female immunodeficient mice (NOD/SCID/IL2RG -null) showed that female recipients displayed higher engraftment efficiency compared to male [25]. In this study, the difference in B cell population among cloned littermates carrying same 
genetic modification was unexpected. We speculate that this discrepancy is probably due to unexpected changes in epigenetic make-up of the $\mathrm{X}$ chromosome. Mammalian IL2RG orthologs are typically located on the $\mathrm{X}$ chromosome and in female one of the $\mathrm{X}$ chromosomes is inactivated during early development. Clones are known to have abnormally skewed pattern of X inactivation [30], and this could be a reason behind the differences in the level of B cells among IL2RG knockout pigs produced in this study. Our further studies will focus on the functional differences in IL2RG between genders in pigs. Also, modification of epigenetic pattern in same littermate produced in this study will be additionally studied.

\section{Conclusions}

Genome editing by CRISPR/Cas9-mediated technology represents a practical strategy for the production of genetically engineered pigs. Using this technology enabled inactivation of IL2RG gene in pigs. In this study, we generated IL2RG knockout female pigs showing phenotypic characterization of SCID. This IL2RG knockout female pig model will greatly contribute not only to cancer and stem cell research but also to preclinical evaluations of the transplantation of pluripotent stem cells, such as iPS cells.

\section{Additional file}

Additional file 1: Table S1. Oligos used to introduce sgRNA into px330. Each pair of forward and reverse primers were annealing and ligated into the PX330 vector. Table S2. Primers used to generate template DNA for in vitro transcription to produce sgRNA and mRNA form of Cas9. Table S3. Primers used to genotype IL2RG mutations introduced by CRISPR/Cas9 system. The extend primers were used to genotype IL2RG from fetus 3 and 6. Table S4. The mutation of fetus. Two fetus contained hemizygous mutation in IL2RG, other two fetus had biallelic mutation, and 2 fetus had presumable large deletion (>1.9kb). (DOCX $22 \mathrm{~kb}$ )

\section{Abbreviations}

COC: Cumulus oocyte complex; DPBS: Dulbecco's phosphate buffered saline; IHC: Immunohistochemistry; NK: Natural killer; PBMCs: Peripheral blood mononuclear cells; PZM-3: Porcine zygote media 3; SCNT: Somatic cell nuclear transfer; sgRNA: Single guide RNA; T7E1: T7 endonuclease l; tracrRNA: Trans-activating CRISPR RNA; XSCID: X-linked severe combined immunodeficiency

\section{Acknowledgments}

We thank Dr. Sangchul Kang and staff in the laboratory in Optipharm corporation for histological analysis and staff in the public instruments center for FACS.

\section{Funding}

This study was not supported by any funding.

\section{Availability of data and materials}

We will share the data.

\section{Authors' contributions}

Conceived and designed the experiments : JK KL KP Performed the experiments: JK BC JR EL SA DJ SC Embryo transfer : YY JL NJ SC Analyzed the data : JK BC, KL Wrote the paper: JK KL KP. All authors have read and accepted the manuscript.

\section{Competing interests}

JK, BC, EL, YY, SA, JL and DJ are employees of MGENPLUS, Inc.. KP is a shareholder of MGENPLUS, Inc..

\section{Consent for publication}

Not applicable.

\section{Ethics approval}

This study was approved by the Ethical Committee of MGENPLUS co.Ltd., Seoul, Korea. Written informed consent forms were obtained from all subjects.

\section{Author details}

'MGENPLUS Biotechnology Research Institute, Seoul 08511, South Korea. ${ }^{2}$ Department of Animal Science \& Technology, Sunchon National University, Suncheon, 57922, South Korea. ${ }^{3}$ Department of Animal and Poultry Sciences, Virginia Tech, Blacksburg, VA, USA. ${ }^{4}$ Department of Large Animal Clinical Sciences, Virginia-Maryland College of Veterinary Medicine, Virginia Tech, Blacksburg, VA, USA

Received: 18 August 2016 Accepted: 18 October 2016

Published online: 03 November 2016

References

1. Brouns SJ, Jore MM, Lundgren M, Westra ER, Slijkhuis RJ, Snijders AP, Dickman MJ, Makarova KS, Koonin EV, van der Oost J. Small CRISPR RNAs guide antiviral defense in prokaryotes. Science. 2008;321(5891):960-4.

2. Buckley RH. Molecular defects in human severe combined immunodeficiency and approaches to immune reconstitution. Annu Rev Immunol. 2004;22:625-55.

3. Cao X, Shores EW, Hu-Li J, Anver MR, Kelsall BL, Russell SM, Drago J, Noguchi M, Grinberg A, Bloom ET, et al. Defective lymphoid development in mice lacking expression of the common cytokine receptor gamma chain. Immunity. 1995;2(3):223-38.

4. Cong L, Ran FA, Cox D, Lin S, Barretto R, Habib N, Hsu PD, Wu X, Jiang W, Marraffini LA, Zhang F. Multiplex genome engineering using CRISPR/Cas systems. Science. 2013;339(6121):819-23.

5. DiSanto JP, Muller W, Guy-Grand D, Fischer A, Rajewsky K. Lymphoid development in mice with a targeted deletion of the interleukin 2 receptor gamma chain. Proc Natl Acad Sci U S A. 1995;92(2):377-81.

6. Hai T, Teng F, Guo R, Li W, Zhou Q. One-step generation of knockout pigs by zygote injection of CRISPR/Cas system. Cell Res. 2014;24(3):372-5.

7. Honma D, Uenishi H, Hiraiwa H, Watanabe S, Tang W, Kiyokawa N, Fujimoto J, Yasue H, Sakimura K. Cloning and characterization of porcine common gamma chain gene. J Interferon Cytokine Res. 2003;23(2):101-11.

8. Huang J, Guo X, Fan N, Song J, Zhao B, Ouyang Z, Liu Z, Zhao Y, Yan Q, Yi X, Schambach A, Frampton J, Esteban MA, Yang D, Yang H, Lai L. RAG1/2 knockout pigs with severe combined immunodeficiency. J Immunol. 2014;193(3):1496-503.

9. Ishikawa F, Yasukawa M, Lyons B, Yoshida S, Miyamoto T, Yoshimoto G, Watanabe T, Akashi K, Shultz LD, Harada M. Development of functional human blood and immune systems in NOD/SCID/LL2 receptor \{gamma\} chain(null) mice. Blood. 2005;106(5):1565-73.

10. Ito M, Hiramatsu H, Kobayashi K, Suzue K, Kawahata M, Hioki K, Ueyama Y, Koyanagi Y, Sugamura K, Tsuji K, Heike T, Nakahata T. NOD/SCID/ gamma(c)(null) mouse: an excellent recipient mouse model for engraftment of human cells. Blood. 2002;100(9):3175-82.

11. Jinek M, Chylinski K, Fonfara I, Hauer M, Doudna JA, Charpentier E. A programmable dual-RNA-guided DNA endonuclease in adaptive bacterial immunity. Science. 2012;337(6096):816-21.

12. Kang JT, Kwon DK, Park AR, Lee EJ, Yun YJ, Ji DY, Lee K, and Park KW. Production of a1,3-galactosyltransferase targeted pigs using transcription activator-like effector nuclease-mediated genome editing technology. J Vet Sci. 2016;17(1):89-96

13. Kragh PM, Nielsen AL, Li J, Du Y, Lin L, Schmidt M, Bogh IB, Holm IE, Jakobsen JE, Johansen MG, Purup S, Bolund L, Vajta G, Jorgensen AL. Hemizygous minipigs produced by random gene insertion and handmade cloning express the Alzheimer's disease-causing dominant mutation APPsw. Transgenic Res. 2009;18(4):545-58.

14. Lee K, Kwon DN, Ezashi T, Choi YJ, Park C, Ericsson AC, Brown AN, Samuel MS, Park KW, Walters EM, Kim DY, Kim JH, Franklin CL, Murphy CN, Roberts 
RM, Prather RS. Engraftment of human iPS cells and allogeneic porcine cells into pigs with inactivated RAG2 and accompanying severe combined immunodeficiency. Proc Natl Acad Sci U S A. 2014;111(20):7260-5.

15. Lee K, Redel BK, Spate L, Teson J, Brown AN, Park KW, Walters E, Samuel M Murphy CN, Prather RS. Piglets produced from cloned blastocysts cultured in vitro with GM-CSF. Mol Reprod Dev. 2013;80(2):145-54.

16. Lei S, Ryu J, Wen K, Twitchell E, Bui T, Ramesh A, Weiss M, Li G, Samuel H, Clark-Deener S, Jiang X, Lee K, Yuan L. Increased and prolonged human norovirus infection in RAG2/IL2RG deficient gnotobiotic pigs with severe combined immunodeficiency. Sci Rep. 2016;6:25222.

17. Leonard WJ. The molecular basis of X-linked severe combined immunodeficiency: defective cytokine receptor signaling. Annu Rev Med. 1996;47:229-39.

18. Li D, Qiu Z, Shao Y, Chen Y, Guan Y, Liu M, Li Y, Gao N, Wang L, Lu X, Zhao $Y$, Liu M. Heritable gene targeting in the mouse and rat using a CRISPR-Cas system. Nat Biotechnol. 2013;31(8):681-3.

19. Ma Y, Zhang X, Shen B, Lu Y, Chen W, Ma J, Bai L, Huang X, Zhang L. Generating rats with conditional alleles using CRISPR/Cas9. Cell Res. 2014;24(1):122-5.

20. Mashimo T, Takizawa A, Voigt B, Yoshimi K, Hiai H, Kuramoto T, Serikawa T. Generation of knockout rats with $X$-linked severe combined immunodeficiency (X-SCID) using zinc-finger nucleases. PLoS One. 2010;5(1):e8870.

21. McDermott SP, Eppert K, Lechman ER, Doedens M, Dick JE. Comparison of human cord blood engraftment between immunocompromised mouse strains. Blood. 2010;116(2):193-200.

22. Mestas J, Hughes CC. Of mice and not men: differences between mouse and human immunology. J Immunol. 2004;172(5):2731-8.

23. Niu Y, Shen B, Cui Y, Chen Y, Wang J, Wang L, Kang Y, Zhao X, Si W, Li W, Xiang AP, Zhou J, Guo X, Bi Y, Si C, Hu B, Dong G, Wang H, Zhou Z, Li T, Tan T, Pu X, Wang F, Ji S, Zhou Q, Huang X, Ji W, Sha J. Generation of genemodified cynomolgus monkey via Cas9/RNA-mediated gene targeting in one-cell embryos. Cell. 2014;156(4):836-43.

24. Noguchi M, Yi H, Rosenblatt HM, Filipovich AH, Adelstein S, Modi WS, McBride OW, Leonard WJ. Interleukin-2 receptor gamma chain mutation results in X-linked severe combined immunodeficiency in humans. Cell. 1993:73(1):147-57.

25. Notta F, Doulatov S, Dick JE. Engraftment of human hematopoietic stem cells is more efficient in female NOD/SCID/IL-2Rgc-null recipients. Blood. 2010;115(18):3704-7.

26. Pracy JP, White A, Mustafa Y, Smith D, Perry ME. The comparative anatomy of the pig middle ear cavity: a model for middle ear inflammation in the human? J Anat. 1998;192(Pt 3):359-68.

27. Renner S, Fehlings $C$, Herbach N, Hofmann A, von Waldthausen DC, Kessler B, Ulrichs K, Chodnevskaja I, Moskalenko V, Amselgruber W, Goke B, Pfeifer A, Wanke R, Wolf E. Glucose intolerance and reduced proliferation of pancreatic beta-cells in transgenic pigs with impaired glucose-dependent insulinotropic polypeptide function. Diabetes. 2010;59(5):1228-38.

28. Rogers CS, Stoltz DA, Meyerholz DK, Ostedgaard LS, Rokhlina T, Taft PJ, Rogan MP, Pezzulo AA, Karp PH, Itani OA, Kabel AC, Wohlford-Lenane CL, Davis GJ, Hanfland RA, Smith TL, Samuel M, Wax D, Murphy CN, Rieke A, Whitworth K, Uc A, Starner TD, Brogden KA, Shilyansky J, McCray Jr PB, Zabner J, Prather RS, Welsh MJ. Disruption of the CFTR gene produces a model of cystic fibrosis in newborn pigs. Science. 2008;321(5897):1837-41.

29. Ross JW, Fernandez de Castro JP, Zhao J, Samuel M, Walters E, Rios C, BrayWard P, Jones BW, Marc RE, Wang W, Zhou L, Noel JM, McCall MA, DeMarco PJ, Prather RS, Kaplan HJ. Generation of an inbred miniature pig model of retinitis pigmentosa. Invest Ophthalmol Vis Sci. 2012;53(1):501-7.

30. Senda S, Wakayama T, Yamazaki Y, Ohgane J, Hattori N, Tanaka S, Yanagimachi R, Shiota K. Skewed X-inactivation in cloned mice. Biochem Biophys Res Commun. 2004;321(1):38-44.

31. Seok J, Warren HS, Cuenca AG, Mindrinos MN, Baker HV, Xu W, Richards DR, McDonald-Smith GP, Gao H, Hennessy L, Finnerty CC, Lopez CM, Honari S, Moore EE, Minei JP, Cuschieri J, Bankey PE, Johnson JL, Sperry J, Nathens AB, Billiar TR, West MA, Jeschke MG, Klein MB, Gamelli RL, Gibran NS, Brownstein BH, Miller-Graziano C, Calvano SE, Mason PH, Cobb JP, Rahme LG, Lowry SF, Maier RV, Moldawer LL, Herndon DN, Davis RW, Xiao W, Tompkins RG. Genomic responses in mouse models poorly mimic human inflammatory diseases. Proc Natl Acad Sci U S A. 2013;110(9):3507-12.

32. Shultz LD, Lyons BL, Burzenski LM, Gott B, Chen X, Chaleff S, Kotb M, Gillies SD, King M, Mangada J, Greiner DL, Handgretinger R. Human lymphoid and myeloid cell development in NOD/LtSz-scid IL2R gamma null mice engrafted with mobilized human hemopoietic stem cells. J Immunol. 2005;174(10):6477-89.
33. Sugamura K, Asao H, Kondo M, Tanaka N, Ishii N, Ohbo K, Nakamura M, Takeshita T. The interleukin-2 receptor gamma chain: its role in the multiple cytokine receptor complexes and T cell development in XSCID. Annu Rev Immunol. 1996:14:179-205.

34. Suzuki S, Iwamoto M, Saito Y, Fuchimoto D, Sembon S, Suzuki M, Mikawa S, Hashimoto M, Aoki Y, Najima Y, Takagi S, Suzuki N, Suzuki E, Kubo M, Mimuro J, Kashiwakura Y, Madoiwa S, Sakata Y, Perry AC, Ishikawa F, Onishi A. II2rg gene-targeted severe combined immunodeficiency pigs. Cell Stem Cell. 2012;10(6):753-8.

35. Takeshita T, Asao H, Ohtani K, Ishii N, Kumaki S, Tanaka N, Munakata H, Nakamura M, Sugamura K. Cloning of the gamma chain of the human IL-2 receptor. Science. 1992;257(5068):379-82.

36. Traggiai E, Chicha L, Mazzucchelli L, Bronz L, Piffaretti JC, Lanzavecchia A, Manz MG. Development of a human adaptive immune system in cord blood cell-transplanted mice. Science. 2004;304(5667):104-7.

37. Wang $H$, Yang $H$, Shivalila CS, Dawlaty MM, Cheng AW, Zhang F, Jaenisch R. One-step generation of mice carrying mutations in multiple genes by CRISPR/Cas-mediated genome engineering. Cell. 2013;153(4):910-8.

38. Watanabe M, Nakano K, Matsunari H, Matsuda T, Maehara M, Kanai T, Kobayashi M, Matsumura Y, Sakai R, Kuramoto M, Hayashida G, Asano Y, Takayanagi S, Arai Y, Umeyama K, Nagaya M, Hanazono Y, Nagashima H. Generation of interleukin-2 receptor gamma gene knockout pigs from somatic cells genetically modified by zinc finger nuclease-encoding mRNA. PLoS One. 2013;8(10):e76478.

39. Wiedenheft B, Sternberg SH, Doudna JA. RNA-guided genetic silencing systems in bacteria and archaea. Nature. 2012:482(7385):331-8.

40. Yang $H$, Wang $H$, Shivalila CS, Cheng AW, Shi L, Jaenisch R. One-step generation of mice carrying reporter and conditional alleles by CRISPR/Casmediated genome engineering. Cell. 2013;154(6):1370-9.

41. Yoshioka K, Suzuki C, Tanaka A, Anas IM, Iwamura S. Birth of piglets derived from porcine zygotes cultured in a chemically defined medium. Biol Reprod. 2002;66(1):112-9.

42. Zhao J, Ross JW, Hao Y, Spate LD, Walters EM, Samuel MS, Rieke A, Murphy CN, Prather RS. Significant improvement in cloning efficiency of an inbred miniature pig by histone deacetylase inhibitor treatment after somatic cell nuclear transfer. Biol Reprod. 2009;81(3):525-30.

43. Zschaler J, Schlorke D, Arnhold J. Differences in innate immune response between man and mouse. Crit Rev Immunol. 2014;34(5):433-54.

\section{Submit your next manuscript to BioMed Central and we will help you at every step:}

- We accept pre-submission inquiries

- Our selector tool helps you to find the most relevant journal

- We provide round the clock customer support

- Convenient online submission

- Thorough peer review

- Inclusion in PubMed and all major indexing services

- Maximum visibility for your research

Submit your manuscript at www.biomedcentral.com/submit
) Biomed Central 